Supplement of Web Ecol., 19, 53-63, 2019

https://doi.org/10.5194/we-19-53-2019-supplement

(C) Author(s) 2019. This work is distributed under

the Creative Commons Attribution 4.0 License.

(c) (1)

Supplement of

\title{
Impact of land-use change in mountain semi-dry meadows on plants, litter decomposition and earthworms
}

Ines Jernej et al.

Correspondence to: Ines Jernej (ines.jernej@gmx.net)

The copyright of individual parts of the supplement might differ from the CC BY 4.0 License. 


\section{Supplementary Table S1}

Table S1: Further information of site characteristics of abandoned and managed mountain meadows during the measurement period.

\begin{tabular}{|c|c|c|}
\hline & Abandoned meadows & Managed meadows \\
\hline Exposition & South-facing slopes & South-facing slopes \\
\hline Soil type & Cambisol & Cambisol \\
\hline Soil moisture (\%) & $33.48 \pm 7.96$ & $34.63 \pm 5.48$ \\
\hline Soil temperature $\left({ }^{\circ} \mathbf{C}\right)$ & $23.36 \pm 4.65$ & $22.89 \pm 5.73$ \\
\hline Size $\left(\mathrm{m}^{2}\right)$ & $573-3,370$ & $1,095-4,500$ \\
\hline
\end{tabular}

